\title{
Editor's Note: Corporeal (W)RI(gh)TEs: New Perspectives on Bodies as Categories of Research
}

Bodies are staged in this issue of $D R J$ in quite diverse ways as a key category of research. The topics vary from dance and human rights and dance as social activism to re-enactment in contemporary choreography, kinesthetic empathy, and a dancer-/event-centered historiography based on archival research. Bodies emerge in these texts as triangulated by the interwoven subjects of human rights, writing (as a staged activity and an archival excrescence), and rite as a cultural process that demands expression. Hence the bizarre "keyword" of my title-(W)RI(gh)Tes-as it conflates, or attempts to blend together, the words Rite, Write, and Right. Each contribution to these pages enjoins the intertwined motifs figured in this strange neologism as it follows its own analytic trajectory. It is a matter of the "re-righting of history"; of a therapeutic and creative rite designed to recover a ruined past and to reconfigure it (to re-right it); of the human rights addressed in reconstructing that history-geographically, historiographically, choreographically, performatively, and sympathetically within the body of the spectator; of taking the past out of the archive (or dancing in the archive) in order to invent anew; of asking by what "right" history is written in a certain way, and what the bodily experience of the dancer might change in that history; and of reconsidering the body of the audience for live dance, its kinesthetic pleasures and displeasures.

Kendall Thomas, collaborator with William Forsythe on the creation of Human Writes, gives us unique insight into the genesis and concepts of that performance installation in a Dialogue with panelists Thomas Keenan and Mark Franko (transcribed from a public event at Lincoln Center in 2009). Thomas explains the genesis of structural complexities of this work as they relate to the human rights struggle-the dancers are engaged in writing the Universal Declaration of Human Rights while being impeded from doing so by the audience that visits the installation. A strange rite is enacted with an undeniable intellectual dimension that centers the dilemma of human rights on the performed relationship between the body and writing.

Ariel Scott Osterweiss, in "Performing Acupuncture on a Necropolitical Body: Choreographer Faustin Linyekula's Studios Kabako in Kisangani, Democratic Republic of Congo," discusses Faustin Linyekula's choreography, workshops, and social activism through a network of studios he is developing in his hometown in the Democratic Republic of Congo. She sees the society of the DRC as a necropolitical body-a body resigned to a 
culture of death-within which Linyekula's initiatives are likened to acupuncture applied to the body politic, here understood quite geographically as a network of studios that can perform social healing.

Andre Lepecki's "The Body as Archive: Will to Re-Enact and the Afterlives of Dances" deals with the contemporary and experimental phenomenon of the re-enactment of past performances. In his discussion of three important examples, Lepecki posits the notion of the body itself as an archive, and the act of dancing as "archiving." Rather than leading to deathly reconstruction, however, this bold move points instead to a choreographic afterlife central to contemporary creativity. We see, by the way, how dance analysis can illuminate the thinking of Michel Foucault and Gilles Deleuze.

In "Kinesthesia, Empathy, and Related Pleasures: An Inquiry into Audience Experiences of Watching Dance," Matthew Reason and Dee Reynolds revisit the kinetic experience of audiences for live dance. The authors outline the findings of their extensive qualitative research into what attracts audiences to dance, what pleasures and displeasures they find there. Notably, they reexamine the idea of affect and how it operates in the perception of the body in motion performing various kinds of dance. Along the way, they introduce a welcome complexification of influential theories such as John Martin's metakinesis and relate their findings to contemporary interest in neuroaesthetics as well.

In a model of archival research into the Ballets Russes tours of I9I6-I9I7 in the United States, Hanna Järvinen revises the consecrated interpretation of Diaghilev, Nijinsky, and the company in her "Failed Impressions: Diaghilev's Ballets Russes in America, I916." Järvinen, in re-writing history, returns the proper rights to Nijinsky as the intelligent and effective artist and director whose reputation was sullied by the Diaghilev machine, or what she calls the hegemonic interpretation of that strand of dance history. Her essay also makes an important plea for a different dance historiography, one more attentive to the actual events out of which performances emerge, and to the actual bodies who do that performing as being in situation.

This issue introduces a Books Received section that should give readers an idea of the broader publication picture within which appear the books reviewed in $D R J$.

Mark Franko

Editor, Dance Research Journal 